\title{
Documental y Peronismo
}

Ana Amado

Universidad de Buenos Aires 


\section{Resumen}

El peronismo de los años cincuenta - su ideario, sus realizaciones, el discurso y la figura de sus líderes máximos, junto a la abundante producción iconográfica y sonora producida en el primer y segundo períodos de su gobierno - es hoy profusamente recuperado por diversos lenguajes artísticos. Antiguas y nuevas imágenes pictóricas, filmicas y mediáticas que retornan sobre aquel movimiento de masas circulan por espacios tan impensados como festivales de cine y museos dedicados a muestras de vanguardia y en programaciones especiales o en series ficcionales de televisión. Esta visibilidad insistente se deja interrogar en principio desde los términos del debate actual sobre el populismo y su relación con la democracia; a la vez que los peculiares rasgos de hibridación de temporalidades, lenguajes $y$ formatos ofrecidos por algunas obras.

\section{Palabras-chave}

Peronismo, visibilidade, arte, filme documentário

\section{Abstract}

Peronism of the $1950 \mathrm{~s}$ - its ideas, achievements, its discursive formations and the figuration of its highest leaders, in combination with its abundant iconographic and sound production put out during its first and second gubernatorial periods - is profusely recuperated in the Argentine cultural present through various artistic languages. Old and new painted, filmic, and media images about this mass movement circulate through unexpected spaces such as film festivals, museums dedicated to avant-garde exhibits, and in special programs or fictional shows on television. This persistent visibility can be interrogated from the vantage point of current debates on populism and its relation with democracy, as well as concerning its peculiarly hybrid temporalities of languages and forms offered by particular works. 


\section{Politizaciones de una estética}

Cuando una era se derrumba, la Historia se descompone en imágenes y no en relatos. W.Benjamin, Pasajes.

$\mathrm{E}$

1 peronismo, condensado en sus mitos y etapas históricas -el de los años cincuenta, sus figuras centrales, su ideario y realizaciones, su copiosa producción iconográfica y también las complejas y violentas circunstancias de su retorno en los setentaes hoy profusamente recuperado por diversos lenguajes artísticos. Antiguas y nuevas imágenes pictóricas, fílmicas y mediáticas inspiradas en aquel movimiento de masas circularon recientemente por espacios tan impensados como un festival de cine y un museo dedicados a muestras de vanguardia, por escenarios teatrales y en series de ficción de los canales de televisión oficiales. ${ }^{\prime}$

1. Varios documentales que con estéticas disímiles aluden al peronismo y de los cuales se ocupará este artículo, se exhibieron en el $9^{\circ}$ Festival de Cine Independiente de Buenos Aires, Bafici, realizado del 3 al 13 de abril de este año. A la vez, en el marco del mismo Festival se proyectó Perón. Sinfonia de un sentimiento, de Leonardo Favio (1994-1998) en la retrospectiva dedicada a este realizador en el Museo de Arte Latinoamericano, MALBA. Simultáneamente, la televisión estatal presentó la virtualmente desaparecida segunda película de Solanas y Gettino Actualización politica y doctrinaria para la toma del poder (1971), donde el viejo caudillo, entrevistado por los autores en su exilio madrileño, realiza en 240 minutos un repaso minucioso de las políticas de su gobierno derrocado 16 años antes. Por su parte, la programación del canal del Gobiemo de la ciudad de Buenos Aires, incluyó una "sitcom" en clave paródica, Mi señora es una espia, creada y protagonizada por Andrea Garrote, Rafael Spregelburd, entre otras jóvenes figuras relevantes del off teatral. La serie transcurre en el inmediato posperonismo del ' 55 bajo la estricta censura impuesta por los golpistas 
"Podemos decir de él lo que queramos. Proteo es inalterable a través de sus metamorfosis", decía Martínez Estrada poco después de su destitución en la mitad de los 50s y desde su proverbial encono con ese régimen. ${ }^{2}$ A partir de entonces, transformando la amenaza en profecía cumplida, multiforme y mutante, el peronismo no cesa de desafiar el tiempo irrumpiendo cada tanto en el espacio político y/ o cultural a través de distintos géneros y versiones.

La multiplicación de producciones con esta perspectiva suele promover, en cada ocasión, interpretaciones que las relacionan con una más o menos solapada "operación" política, bajo el criterio, derivado del rechazo o la desconfianza que tradicionalmente despierta el peronismo, de ver cada obra como una maniobra. ${ }^{3}$ A mediados de los 90 , por ejemplo, la coincidencia de la irrupción pública de voces testimoniales de la militancia de los 70 s con una serie de manifestaciones artísticas centradas en su ícono más célebre, Eva Perón, condujeron a que éstas no se descifraran en sí mismas, sino apenas como signos del retorno de una generación asociada al peronismo y políticamente marcada con el rojo de la violencia. ${ }^{4}$ Pero la simultaneidad de referencias con las que el peronismo emerge ahora - más allá de que nunca dejó de constituir un permanente y

a su mención, desde el punto de vista de un ama de casa egresada de la "escuela de espias femeninas" del movimiento y que cumple tareas de apoyo a la resistencia entre decorados que reconstruyen los interiores domésticos bajo el modelo de la "felicidad justicialista".

2. E. Martínez Estrada, ¿Qué es esto? Catilinarias, Buenos Aires: Ed.Colihue/ Biblioteca Nacional, 2005.

3. Cf. el análisis de A. Ballent del documental Perón de Favio comparado con la obra plástica de Daniel Santoro, en "La traición de las imágenes. Recuperación del peronismo histórico", Punto de Vista 87, Abril 2007.

4. En aquel momento hubo varias novelas (una de ellas notoria, menos por la resonancia hagiográfica del título que por su repercusión editorial en varios idiomas: Santa Evita, de Tomás Eloy Martínez, 1995) y tres películas que coincidian en llevar su nombre como rótulo, pero diferian en su formato y en su visión del personaje (Evita, 1995, el musical de Alan Parker con Madonna; Eva Perón, 1996, la ficción semi-biográfica de Juan Pablo Desanzo con guión de Juan Pablo Feinman y el documental Evita.La tumba sin paz, de Tristán Bauer con guión de Miguel Bonasso) pasaron de manera más o menos simultánea por las carteleras de Buenos Aires. 
productivo foco de inspiración literaria y de fórmulas críticas en registros tan mutantes como su objeto- se ofrece menos clara para asociaciones de índole ideológica o política con la coyuntura. En todo caso, su presente reaparición como experiencia estético-política y la visibilidad insistente de imágenes que lo tienen como referente, puede situarse aproximadamente en los inicios del gobierno Kirchner. También en el marco del debate sobre el peronismo y posperonismo trabajado por distintos ensayistas, de las políticas de corte popular y las remisiones a un ideario nacional con el que se identifica el propio gobierno y de las criticas de "populista" que recibe de parte de las posturas liberales. Es posible que la cuestión merezca una interrogación más extensa y considero importante el contexto que rodea la aparición de la obras, pero también que las condiciones y las características del enlace entre ambos pueden surgir de una mirada cercana a las obras mismas. Mi intención por lo tanto es realizar una aproximación a la propuesta formal y temática de algunos films documentales de circulación reciente, desde las sugerentes correspondencias que hay en ellos respecto de su referente y desde los procedimientos de hibridación de lenguajes, temporalidades y formatos como inscripción formal de la memoria del peronismo, cuyos elementos -que van de la Historia al mito y viceversacontinúan siendo pasibles de reapropiaciones y lecturas que llevan las marcas de cada presente en que aquellas se realizan.

Mis referencias centrales serán para Pulqui. Un instante en la patria de la felicidad, de Alejandro Fernández Moujan, que registra el proceso de construcción a escala de un avión "justicialista" realizada por el artista Daniel Santoro, cuya obra pictórica, inspirada desde hace una década en la iconografía mítica peronista, ocupa también un lugar destacado en el film. ${ }^{5} \mathrm{Y}$ vinculados con Pulqui, el último documental de Fernando Solanas, Argentina latente último film de la trilogía que este realizador dedicó, desde el estallido social de 2001, a determinar las causas y responsabilidades procesistas y

5. Pulqui. Un instante en la patria de la felicidad, Argentina, 2006. Idea original de Marcelo Céspedes. Guión, cámara, montaje y dirección: Alejandro Fernández Moujan. Sonido: Jésica Suárez. Producción: M.Céspedes, Cine Ojo. 
menemistas del catastrófico deterioro económico social del país. ${ }^{6}$ Los relatos que en la película de Solanas se formulan en tiempo pasado para aludir al momento originario y fundacional de logros científicos y tecnológicos, puede ponerse en vinculación con el enunciado que sobre el mismo tema expone en un presente apasionado el film Perón. Sinfonia de un sentimiento, de Leonardo Favio.?

En cada caso se alude a un avión a reactor, suma de diseño y tecnología de punta fabricado durante el gobierno de Perón en 1947 (Pulqui I), perfeccionado en 1951 (Pulqui II) y "caído" como proyecto junto con su gobierno en 1955. Figura emblema entre otras máquinas de producción nacional o fetiche de aproximación a las grandes potencias -competía con el estadounidense Sabre F86 y el soviético Mig 15- , el avión "justicialista” se recorta en el discurso de la utopía industrialista y tecnológica en su condición de promotora de la transformación social emprendida por el peronismo, sentido utópico que es aludido de manera literal o figurada en los documentales mencionados.

En verdad, las máquinas voladoras, reales o imaginarias aparecían asociadas a las fantasías de cambio de principios de siglo pasado, cuando el pulso de la cultura en los países occidentales era, en palabras de Susan Buck-Morss, una corriente alterna de finales imaginados y de nuevos comienzos". ${ }^{8}$ Los aviones y sus pilotos se convirtieron entonces en el fetiche predilecto de las artes visuales y de la ciencia ficción literaria en un viaje estético planetario que rozó

6. Argentina latente, Argentina, 2006. Dirección y Guion: Fernando Solanas, Producción: Cinesur/ Wanda Vision/ Les Films du Sud. Las anteriores fueron Memorias del saqueo (2002) y La dignidad de los nadies (2004). En su último documental Solanas se ocupa del quebranto sufnido por los recursos naturales, industriales, científicos y tecnologicos del pais cuyo esplendor pretérito - 0 como indica el título del film, latente, a la espera de las decisiones politicas adecuadas para corregir lo descalabrado- son narrados por científicos, investigadores, trabajadores o estudiantes quienes resisten hoy en cada puesto con el motor de una memoria intacta.

7. Perón. Sinfonía del sentimiento, Argentina, 1994-2000. Guión y dirección: Leonardo Favio.

8. Susan Buck-Morss, Mundo soñado y catástrofe. La desaparición de la utopia de masas en el Este y el Oeste, Madrid: La balsa de la Medusa, 2004, p. 62. 
la Argentina. Unida deficientemente por el ferrocarril, durante los festejos del Primer centenario de la revolución de Mayo en 1910 proliferaban diseños de la ciudad de Buenos Aires con proyecciones futuristas que despegaban el transporte de la tierra y plagaban ficcionalmente el espacio con artefactos aéreos de todo tipo.

La vanguardia estética de principio de siglo representó estos shows electromecánicos y les dio una organización plástica con visión de futuro, impulso utópico apropiado, como se sabe, por la revolución bolchevique y el fascismo italiano, que canalizaron esa energía hacia su proyecto político.

El peronismo, en plena posguerra, no conoció vasos comunicantes similares entre política y producción artística, pero dinamizaba su poder con el "suplemento utópico" 9 que obtenia de la profusa circulación de imágenes fílmicas que destinaba a la promoción tanto de su impulso productivista, como de la nueva relación hombre-máquina (relación que en términos deportivos, por ejemplo, era encarnada por el corredor argentino de Fórmula 1 Juan Manuel Fangio, con sus cinco campeonatos mundiales entre 1951 y 1956).

Daniel Santoro, artista plástico que proclama su filiación peronista, vuelve a aquellas fuentes con la convicción de que "el arte político argentino excluyó de su canon al peronismo, (movimiento que) tras diez años de su período fundacional dejó un repertorio iconográfico sólo comparable al que generaron las grandes ideologías del siglo XX". ${ }^{10}$ Santoro compensa ese descarte con una decidida

9. La expresión es de Hubertus Gassner, para designar la producción de los artistas de la vanguardia soviética, en "The constructivists", p. 299. Citado por Buck-Morss, en Mundo soñado y catástrofe, p. 83-84.

10. Daniel Santoro, "La mamá de Juanito y una leyenda del bosque justicialista", en Mundo peronista, Buenos Aires: Ed. La Marca, Sutern, Cine Ojo, 2006, p.48 . Santoro explica que el arte del peronismo se nutrió en el de esas ideologias, “ desde la gráfica modernista del fascismo italiano y del constructivismo soviético hasta las hogareñas campañas del confort norteamericano de posguerra. Si a esto sumamos los trágicos registros de bombardeos, iglesias en llamas, lutos obligatorios, amputaciones y momias itinerantes, el conjunto es abrumador $\mathrm{e}$ ineludible. Sin embargo, tal vez cumpliendo los artículos del decreto ( se refiere a la ley de la dictadura militar de 1955 que prohibia el uso o tenencia de cualquier imagen o símbolo que aludiera al gobierno depuesto), la mayoria de nuestros pintores ignoraron aquel periodo". Ibid. 
reinterpretación: figuras célebres del arte de izquierda, como las de Juanito Laguna y Ramona Montiel, el niño abandonado en un basural y su madre prostituta de una de las series sociales de Antonio Berni de los 60 s, son retomados en su obra como parte del paisaje posperonista de pérdida y exclusión. ${ }^{11} \mathrm{O}$ emprende otras performances reparadoras, como la que monta con la figura del Pulqui II para exponer la transición que va del avión justicialista como objeto en el mundo, a representarlo como modelo de las vías posibles de imaginación en el presente. Una operación que podría entenderse como retrospectiva -podría decirse, restitutiva- en el objetivo de reunir arte y política bajo ese signo ideológico.

En esta dirección, el avión "justicialista” es una figura idónea para establecer aquí un enlace entre los documentales mencionados, ya que el rol indeciso entre metáfora y objeto de referencia que adquiere en sus representaciones -uno de ellos incluso lleva por título su nombre y lo ubica en el centro del relato-, revela pistas sobre procedimientos formales abiertamente disímiles de autores que parten de un umbral ideológico afín en relación al peronismo.

Michael Renov menciona las cuatro tendencias que engloban las retóricas/estéticas del documental, en cuanto a principios de construcción, funciones o efectos y que obviamente implican las poéticas y/o políticas específicas del género, en cuanto a las "modalidades del deseo e impulsos que alientan el discurso documental". Tales tendencias serian: Registrar/revelar/ preservar; persuadir o promover; analizar o interrogar; expresar. ${ }^{12}$ Dificilmente pueda adscribirse las películas aludidas a una sola de estas categorías (Renov es conciente de la rigidez de las taxonomías, y relativiza la

11. "( Es extraño) que Antonio Berni haya elegido borrar los rastros de aquel movimiento de masas, rastros con los que seguramente se cruzó buscando por el conurbano bonaerense chapas y residuos para sus excelentes obras de montaje. Sospecho incluso que Ramona Montiel fue peronista y que en algún rincón de su habitación guardaría un altarcito dedicado a Evita. ¿O acaso era una rara prostituta marxista-leninista?", Ibid. P 4.

12. "Towards a Poetics of Documentary", en Michael Renov ed., Theorizing Documentary, New York: Routledge, 1993 (p.21). 
suya admitiendo "fricciones, sobreposiciones, incluso mutuas determinaciones" en la práctica documental): la de Solanas analiza e interroga, pero desde el motor de una persuasión; Favio construye con Perón una obra dentro de las cláusulas del film de propaganda política (su documental nació como "encargo del poder", en el estilo de los realizadores angloamericanos durante la segunda guerra) ${ }^{13}$, pero es innegable la fuerza expresiva del resultado; Fernández Moujan ejecuta un equilibrio delicado entre el registro revelador y la potencia poética de su objeto, sin resignar -igual que los otros autores-, la operación "ética, emocional y demostrativa" 14 que subyace en el documental ideológico o político.

13. El documental se inició en 1994 como un encargo del por entonces gobernador bonaerense Eduardo Duhalde, con fondos de la Fundación Confederal, para estrenarlo al año siguiente en conmemoración de los 50 años del 17 de Octubre de 1945. Pero la obsesividad creativa de Favio precisó varios años hasta lograr esta serie documental, que recrea desde su punto de vista la figura pública y los acontecimientos políticos nacionales e internacionales que giran alrededor de la figura de Juan Domingo Perón y el movimiento peronista. Para este propósito Favio logró reunir documentos de archivo visuales y sonoros notables, entre ellos una filmación casera del festejo de casamiento de Perón y Evita, provista por la colección privada de la familia. Con un discurso audiovisual complejo, combina diversas tecnologias que intervienen las imágenes de archivo y otros materiales históricos con animaciones, ralentis, superposiciones (una mezcla kitsch vanguardista surcada por pájaros agoreros, vacas agonizantes, una paloma blanca que surge de las manos de Evita durante su discurso más virulento, entre decenas de emblemas justicialistas y fondo de coros que transfiguran la marcha de ese movimiento con acordes de Aída, de Mozart, Victor Heredia y Vangelis), y el agregado de inserts con pasajes ficcionales en las que participan dobles especialmente seleccionados a través de exhaustivos castings por su parecido con personajes históricos, - incluidos Perón y Eva- Su duración final es de cinco horas, cuarenta y seis minutos, en un formato de miniserie de seis capítulos. Una vez finalizada, circuló por espacios alternativos (universitarios, sindicales, centros culturales). Antes de su inclusión en la retrospectiva de Leonardo Favio organizada en el Malba durante el $9^{\circ} \mathrm{Bafici}$, se proyectó en la televisión privada en 2002 y en la estatal en 2006.

14. Bill Nichols, Ideology and the Image: Social Representation in the Cinema and other Media, Bloomington: Indiana Press, 1981. Citado en M. Renov, Theorizing Documentary, op.cit. 


\section{Solanas y el destino}

En Argentina latente, la fabricación de este avión -y del final impío de ese proceso- es un dato específico dentro una serie de relatos de signo dramático sobre la industria tecnológica nacional, narrados por personajes relacionados íntimamente con la historia referida, sea por haberla protagonizado en el pasado o por adherir a un legado y resistir contra toda adversidad su aniquilación. "Fue el primer reactor fabricado en el hemisferio sur y el 8vo. en el mundo, que nos puso en el nivel de Francia...", explica hoy el ingeniero Francisco San Martín desde el espacio que resta de la Fábrica militar de aviones en Córdoba, provincia que fue tradicionalmente desde la década del 40 centro de industrias e investigaciones metalmecánicas. Su voz agrega datos y precisa información estadística sobre las versiones sucesivas y perfeccionadas del Pulqui -estrella connotada de la empresa entre otros aviones comerciales, el "Gaucho", el "Pampa" etc.-, apoyada en documentos escritos e ilustradas con imágenes de archivo cuya simultaneidad contrasta una escena de evolución con su interrupción abrupta: la venta sin condiciones, de planos, planes, hombres e ideas a la Lockhead, propietaria desde hace más de una década de la fábrica y sus pertenencias. "Esta fábrica fue la más grande de Centro y Sudamérica, tuvo diez mil empleados, decenas de ingenieros, investigadores y laboratoristas propios. Fue una industria genuina. Ahora quedó como taller de mantenimiento de aviones. La Lockhead Martin no necesitó invertir nada, se le traspasó todo, instalaciones, personal capacitado, todo. El Estado le dio todas las patentes intelectuales de la fabricación, todos los desarrollos de los aviones, el "Pampa" incluído. Porque ahora el 'Pampa' es de la Lockhead. Esta industria no puede ser para nosotros. Así se reprogramó", remata el Ingeniero cuyo testimonio es prolongado por las reflexiones en off de Solanas acerca de éste y de otros ejemplos planteados en su documental, para demostrar su tesis sobre "la capacidad de Argentina de cumplir objetivos tecnológicos complejos", pero a la cual "resabios de su colonización mental le impiden generar un proyecto estratégico propio". 

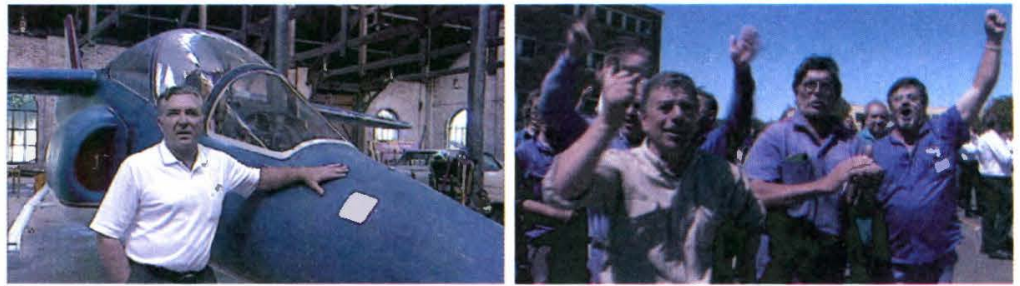

Con este universo de alta complejidad de la fabricación tecnológica, abrumador tanto por la densidad material de sus productos -turbinas, chasis de motores, piezas hidráulicas, locomotoras, barcos, aviones, etc.- como por las leyes de abstracción (o prejuicios de impenetrabilidad) del pensamiento que los edifica, Solanas construye un documental que en lo formal reitera los recursos visuales y retóricos empleados en los films anteriores de su trilogía (me atrevería a decir de sus primeros documentales políticos, sin la impronta de activismo militante de éstos): un discurso fuerte, denunciante y didáctico a la vez, sostenido oralmente por su propia voz off, y rubricada por carteles que anticipan o anclan el sentido de lo que ofrecen los testimonios sucesivos e imágenes de factura impecable. Mientras su alegato se ubica en el centro del sistema, la escena visual alterna sucesivamente las geografías, los paisajes, los problemas, las áreas de producción y con ellas, la intervención de testigos y protagonistas. Con tales piezas formales construye narrativamente ese mundo "duro" casi como un oximoron, según las reglas conmovedoras del drama clásico de auge y caída. Dentro de esa trama argumental, el trayecto del Pulqui resume, a escala, un sentido que Solanas tensiona entre el cumplimiento de un destino aciago y la firmeza de una determinación hacia el futuro. Un ejercicio de memoria de esplendores pretéritos, como prueba de una hipótesis de restauración ulterior. ${ }^{15}$

15. Cada determinación personal es presentada como expresión de una recuperación colectiva, de una emancipación (de una santificación se diría) del pueblo. De inspiración moderna, en el pensamiento de Solanas lo popular se transforma en un destino político. Así, la "utopía de los pueblos originarios" que en America latina tuvo una reflexión propicia en los populismos del siglo $X I X$, el de los caudillos provinciales, y en el XX, el de los caudillos nacionales alienta el discurso anticolonialista de sus documentales desde La hora de los 


\section{Favio y el pasado como presente}

"No es cuestión de adoptar sino en algunas circunstancias de adaptar. Y en otras, de crear. Porque la suprema condición del arte de conducir a los pueblos es precisamente la creación. Y para crear hay que someterse a las circunstancias naturales del hecho que uno pretende crear. Y eso es fundamental..." J.D.Perón, en Actualización política y doctrinaria para la toma del poder (Solanas y Getino, 1971)

La temporalidad con la que Leonardo Favio inscribe el universo de las realizaciones peronistas en Perón. Sinfonía de un sentimiento, en cambio, por la índole misma de su enunciación, se formula en presente. $\mathrm{O}$ dicho de otro modo, en un "tiempo impuro", donde imágenes de redención reemplazan cada punto de vacilación o catástrofe de la historia, a partir de la extraordinaria manipulación de materiales y de reelaboración de documentos visuales para construir esta pieza maestra de anacronía. ${ }^{16}$

En la primera parte del film (y al cabo de la batería de recursos que resumen en menos de una hora los acontecimientos del mundo y del país desde la guerra de 1914 en una palpitante invención visual y sonora que tiene su climax con el 17 de octubre del ' 45 ) las políticas productivistas y de reivindicaciones sociales y culturales del primer gobierno de Perón se mencionan a través de las obras puestas en ejecución con una locución en off que las expone del mismo manera que la propaganda oficial gráfica de aquel régimen en los 50 s, la

hornos y culmina en Argentina latente con sus postulados intactos (aquellos sobre la "necesaria comunidad de naciones latinoamericanas"), bajo la misma lista de liderazgos históricos de San Martín y Bolívar a Allende y al Che, incluyendo a los que levantarán estas banderas en el siglo XXI.

16. George Didi-Huberman, Ante el tiempo, Buenos Aires:Adriana Hidalgo, 2005. Este autor despliega conceptos centrales sobre el anacronismo en el arte y también su relación con la idea misma de la historia como construcción de intrigas, como forma poética o incluso como forma retórica del tiempo explorado, que resultan muy pertinentes con los procedimientos de Favio en esta película, con su extraña conjunción de documental, ficción, historia y apasionada declaración política. 
enumeración en presente. ${ }^{17}$ (En rigor, el segmento tiene un montaje anacrónico, ya que el sentido de aquellas políticas es explicado previamente por Perón a través de una entrevista realizada en 1971, y en la que el caudillo expresa en presente lo sucedido hacía veinte años) ${ }^{18}$. Cada misión constructiva es nombrada con un se impersonal, que remata un verbo en su forma intransitiva (verbos dinámicos y repetitivos, como en el discurso de propaganda): se hace..., se construye..., se edifica..., se traza..., se levanta... etc., en una enumeración interminable de obras cuyo tipo de expresión gramatical sugiere un agente de participación difuso porque sólo apunta a destacar la acción cumplida. Así, los logros resultan potentemente atribuidos a un régimen, a un sistema más que a un líder, si bien su palabra e ideas se presentan como sostén de esa ilimitada efervescencia creadora: su conducción (la voz, los matices, la elegancia oratoria del "efecto Perón", según lo define Horacio González) asoma como la materia abstracta de un resultado, mientras su realización se enuncia con frases afirmativas, "frases que atestiguan". 19

El inicio de la serie, dedicado a la industria pesada y los adelantos tecnológicos (petróleo, minas, gasoductos, diques, aeropuertos, energía atómica con reacción termonuclear controlada,

17. Véase por ejemplo la voluminosa publicación La Nación Argentina Justa, libre y soberana, edición oficial de 1950 "en el año. del Libertador General San Martín" (800 páginas), donde se realiza un pormenorizado informe de las políticas en curso. Su concepción visual es recogida en Perón mediante. Gráfica peronista del período clásico, de Guido Indij, Buenos Aires: La marca editora, 2006.

18. En la cita, Perón presenta las medidas tomadas en su primer gobierno como una cadena de medidas y consecuencias: "El desarrollo es como el apetito, que viene comiendo", dice como introducción a una explicación concisa (atenta a "cuatro factores de progreso: producción, transformación, distribución y consumo", explica), en la que emplea indistintamente verbos en presente y en pasado. Este y otros segmentos similares incluidos en el film de Favio pertenecen a la larga entrevista realizada en Madrid por Solanas y Getino en 1971 y que figuran en el documental Perón. La revolución justicialista, extraviado desde hace mucho tiempo y recientemente recuperado y exhibido por Fernando Martín Peña y Fabio Manes en canal 7 en su ciclo sobre documentales de los setenta durante el mes de abril.

19. Horacio González, en Restos pampeanos, Buenos Aires: Colihue, 2000 (p.340). 
etc.) ofrece el antecedente - enfático en su cualidad fundacional y en la fuerza de su construcción como un ahora- del relato de los tiempos de extravío y de pérdida que presenta el documental de Solanas. Incluido el pasaje dedicado a la fabricación de aviones ("se crea el IAME, complejo compuesto por diez fábricas con nueve mil operarios calificados, cuya evolución arrolladora produjo 200 aviones biplaza, cien aviones Colkin...", etc.) en la que el Pulqui a reacción, igual que cada elemento significativo en una sinfonía, único y a la vez integrado al conjunto, es presentado como "la maravilla de la audacia y la técnica con la que argentina se pone a la vanguardia mundial de ese tipo de desarrollo y es uno de los países del mundo que vuela sus propios aviones a chorro".

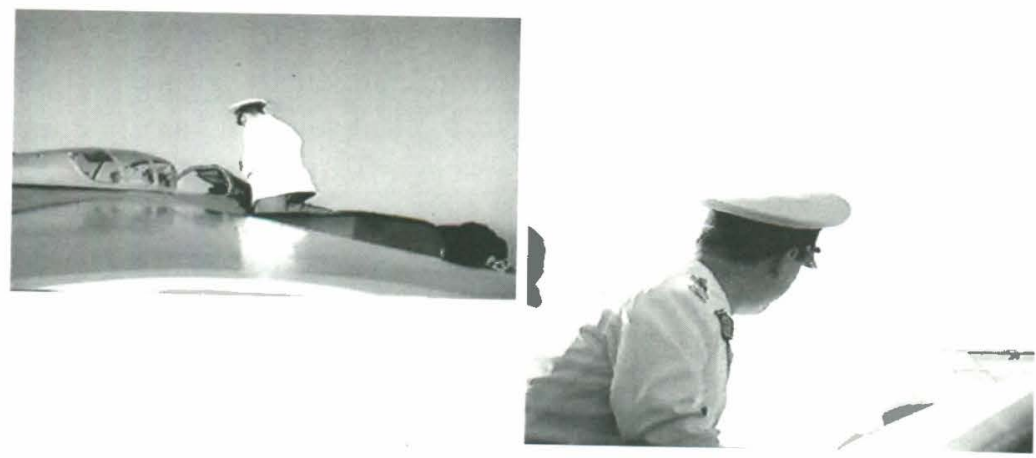

Las imágenes refuerzan el envión transhistórico de la voz off con retazos de invención actual incrustados en la experiencia de origen: planos muy cercanos de Perón admirando el fuselaje del Pulqui, o subiendo con expresión satisfecha a la cabina de la maravilla técnica como un Howard Hughes criollo ante uno de sus juguetes aéreos, son parte de la "reconstrucción documental" con la que Favio duplica la emoción del registro y le imprime una actualidad incesante sin perderse nunca en el simulacro. Su visión sacramental del pasado peronista apuesta fuertemente al aura de los archivos escritos, visuales y sonoros que recolectó masivamente sobre ese movimiento, pero aplica a esos materiales todo el arsenal de los recursos del cine para llevarlos a un verosímil que eterniza pasionalmente la historia. 

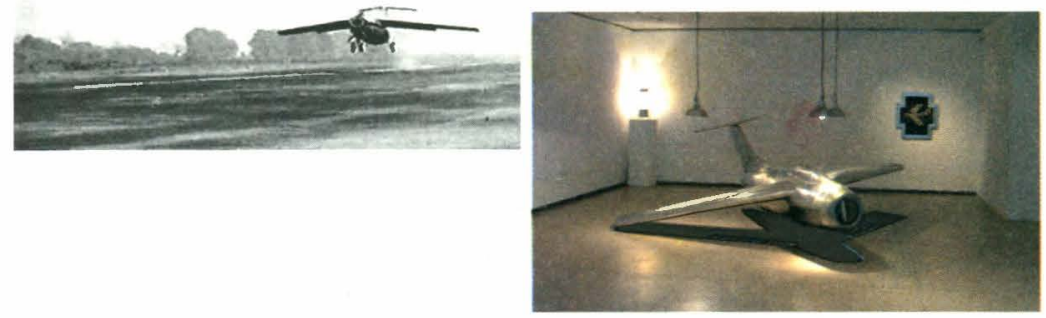

"¿Cuál será el soporte sobre el cual se escribe la historia política? ¿Qué elementos nos auxilian cuando intentamos resucitar su dramaticidad? ¿En qué documentos nos afirmamos para construir un relato? ¿Por qué la película se inicia diciendo que es un documental?" se interrogaba al respecto Gustavo Nahmías en el ensayo que hace algunos años dedicó a Perón... en Confines. ${ }^{20} \mathrm{La}$ respuesta parece evidente: el soporte de la operación documental de Favio sobre la historia política del peronismo, referida con el dramatismo de un canto pasional, es la lengua del mito. No me extenderé aquí sobre esta noción tan fácil de nombrar como complicada de definir, pero su mención vale para insistir en que precisamente el uso del pasado presente, el atrás-adelante del tiempo de la imaginación mítica para volver sobre los hechos de la historia (que aludimos más arriba con el sólo ejemplo de la insistencia del uso del intransitivo en el texto off, pero que incluye el empleo de un

20. Gustavo Nahmías, "Mito y dramaturgia sacramental en la interpretación histórica", Confines $\mathrm{N}^{\circ} 13$, diciembre de 2003. Véase del mismo autor "Memoria y política: el caso Favio", en La memoria en el atril. Entre los mitos de archivo y el pasado de las experiencias, de Horacio González (comp), Buenos Aires: Colihue, 2005, donde en sendas entrevistas, los Jefes de producción de Perón. Sinfonía del sentimiento (Víctor Bassuk y Javier Leoz productores del film describen los pormenores de la reconstrucción de los materiales visuales y sonoros de archivo que realizó Favio, junto a la utilización de dobles para reforzar la representación visual de Perón, de Eva y otros personajes de su entorno político y sindical. 
arrollador repertorio de figuras de intervención en la imagen y el sonido), enlaza paradojalmente el impulso documental de Favio con la invención visual del plástico Daniel Santoro.

\section{Alas de la patria}

\section{"El peronismo crea siempre esa tensión entre realidad y ficción" \\ (Daniel Santoro, en Pulqui. Un instante en la patria de la felicidad)}

El documental peronista de Favio con un verosímil atravesado por el arte del simulacro encuentra su lugar en el Malba, mientras el proceso de construcción a escala del avión Pulqui II para una instalación de museo -la que realizó Daniel Santoro en el museo Caraffa, de Córdoba- es registrado por imágenes que siguen fielmente los pasos de esa inspiración. Y en este pasaje a la museificación de estéticas ligadas al peronismo, se revelan también formas diversas o inversas- tanto del documental, como de las relaciones que entablan las imágenes de distinto origen entre sí y con su referente histórico político. Para Michael Renov, este tipo de experiencias mixtas da al género la ocasión de "medirse con una experiencia y de retrabajarla en el nivel de imágenes (disímiles) y de sonidos (que las acercan en lo temático).".21

Pulqui. Un instante en la patria de la felicidad podría caracterizarse en principio dentro del subgénero documental de estatuto incierto o indecidible en lo autoral o en su mismo contenido, en la medida que se construye, en principio, como una vigilancia sistemática de las etapas que atraviesa una obra escultórica hasta su presentación en una galería artística. Alejandro Fernández Moujan evita la flexión más o menos habitual del documental "de arte" miméticamente adherido a otro lenguaje y del contacto de las imágenes

21. Op. cit., p. 34 . 
filmicas con el "mundo peronista" de Santoro, se descuelga la crónica de una moral y de una disciplina sostenida en una mutua obsesión.

La idea de seguir de comienzo a fin las fases de un proceso creativo es similar a la de su film anterior, Espejo para cuando me pruebe el smoking (2005), ${ }^{22}$ en la que acompañó al escultor Ricardo Longhini durante la elaboración de obras realizadas con elementos recogidos por este artista después de la sublevación popular de diciembre de 2001 (perdigones, cartuchos servidos, piedras, cápsulas de gas, etc.) y con despojos y descartes que arroja la realidad en sus márgenes. En ese doble proceso de producción de sentido el documental de AFM lograba, según escribió Eduardo Grunner, afianzar su autonomía de "film político en segundo grado (...) al elaborar lo trabajado por Longhini como capas superpuestas (...), al explorar otras dimensiones de lo político incluídas en la obra". Y esa otra dimensión, enfatizaba Grunner, "está constituida (en la película) por la tensión entre dos posiciones aparentemente contradictorias: la de la intimidad y la distancia" con el material filmado. ${ }^{23}$

Sostener ese equilibrio virtuoso es sin duda una conquista preciada para un documental que siempre ensaya afirmar su "voz" (voz no fónica sino expositiva, narrativa) en relación a su objeto y en Pulqui no deja de poner en práctica aquellas consignas de sutil emancipación. La cuestión es hasta qué punto el film de AFM se deja habitar por el tema (es decir, cede en intimidad), mientras el movimiento filmico establece distancias al extraer sutilmente su propia cosecha de sentidos de los espacios recorridos, del proyecto colectivo, del mundo locuaz de Santoro, hasta apoderarse de su ritmo y de su "tono". Y terminar instalando en paralelo, -por un natural movimiento metonímico - el trayecto del propio documental con las alternativas sucesivas de entusiasmo, fracaso y recuperación vinculadas a la utopía

22. La producción de este film, como la de Pulqui, es de Marcelo Céspedes, para Cine Ojo. Espejo...se estrenó en septiembre de 2005 y la obras de Longhini se exhibieron en el Centro Cultural Recoleta en octubre del mismo año. Véase el catálogo de la exposición, Ricardo Longhini, Obras 2000-2005, Buenos Aires: Asunto Impreso ediciones, 2005.

23. Ibidem, p.69. 
de "hacer volar" a la réplica construida del avión justicialista. Un tejido de evidencias y relaciones, en suma, que recuerdan la distinción de Pasolini entre el cine de prosa que oculta los elementos que lo constituyen y el cine de vuelo poético que entabla relaciones libres con su referente hasta crear con él "otra cosa".

El avión Pulqui II es una figura extraída del imaginario hiperbólico sobre el primer peronismo que Daniel Santoro reelabora en su obra plástica de la última década. Ni maqueta ni imitación, el proyecto consiste en la idea de construirlo como objeto en escala 2:1 en relación al original, idea rematada por la ocurrencia bizarra de hacerlo "volar". "E1 Pulqui es un objeto heroico, un objeto mitológico de la tecnología nacional", dice Santoro de su objeto, frase que tiene la pasión animista de Favio, y a la vez resuena como variante estética del testimonio del Ingeniero San Martín sobre su existencia técnica en Argentina latente de Solanas. Aunque los datos de su invención y de la técnica espacial comprometida, ceden aquí a la imagen detenida sobre ese punto fugaz de la historia en el que su existencia y su desaparición -coincidente con la caída del gobierno peronista-, arman en torno a ese avión el relato del mito. Un relato que remite a los orígenes y que Santoro densifica con nociones que reúnen tecnología , nación y naturaleza en un cóctel sostenido por un barroco simbolismo visual, apuntalado por una voz del olimpo literario como la de Hölderlin: "La más ansiada ternura, condenada a un ayuno eterno./ Lo que amamos no es más que una sombra./ Para mí, la Naturaleza tan amiga murió/ con los sueños dorados de mi juventud./¡Pobre corazón, en aquellos dichosos días/nunca te sentiste tan lejos de tu verdadera patria./ Por más que busques, nunca volverás a encontrarla;/ consuélate con verla en sueños!'24 Esa patria soñada de la felicidad peronista y de su caída ominosa es la que una y otra vez representan con clima onírico las telas de este artista.

24. Presentación de la exposiciones de Daniel Santoro Un mundo peronista, en el Centro Cultural Recoleta (2001) y Leyenda del bosque justicialista, en Galeria Palatina (2004). 
A esa patria se ingresa como en trance en la película de AFM, con imágenes animadas de los bosques pictóricos de inspiración romántica de Santoro (Arnold Böcklin, Caspar Friedrich entre las citas más evidentes) y guiados por Evita que se interna en él de la mano de una niña escolar de delantal blanco ,ambas como íconos soñantes o soñados. Con el poder de escisión visual y sonora del medio, la secuencia inicial del film es pura síntesis y ensamble de lenguajes: el paisaje boscoso imita el original pictórico, mientras imágenes de archivo de Perón en el vuelo inaugural del Pulqui sobreimprimen sobre aquel su despegue silencioso; desplazado, el off entusiasta del locutor original describe la escena sobre el montaje ágil de ciudades justicialistas de distintas telas de Santoro (con sus edificios emblema indecisos entre el aspecto de una ciudad florentina o la abstracción moderna y ominosa de De Chirico), sobrevoladas siempre por el avión. Planos aéreos por lo tanto alternan puntos de vista y perspectivas en contrapunto con sucesivas escenas de archivo (la felicidad de centenares de niños en los mundos liliputienses que Evita armó a su escala) y su reproducción pictórica.

El documental de AFM define así de entrada su posición, su "operación" como define Ranciere al encadenamiento en cine de imágenes que tienen que ver con regímenes diferentes: "operaciones de la forma para establecer relaciones entre lo decible y lo visible, maneras de jugar con el antes y el después, la causa y el efecto."25

Una vez planteado inicialmente el régimen de encadenamientos, concordancias y diferencias entre las imágenes de una y otro origen, comienza el itinerario actual de producción -de reproducción- del OVJ, del "Objeto Volador Justicialista" como designa al avión Santoro en un pasaje del film. En el proceso, emergen dos espacios y sendos sistemas de producción del arte: el trabajo solitario en el estudio del artista, pura libertad de invención mítica. Allí donde Santoro boceta, dibuja, borra, corrige y avanza en los trazos pictóricos del avión sobre la tela o, en control absoluto de sus mitos

25. Jacques Ranciére, Le destin des images, Paris: La fabrique editions, 2003. p.14. 
íntimos (en sus paisajes peronistas no hay pueblo, sólo emblemas, instituciones, líderes rodeados de lógicas de la cábala y niños), rebosa de objetos el kitsch doméstico de "felicidad peronista", o agrega pinceladas que acorazan los delantales de escolares enlutados y perdidos en la intemperie de bosques sombríos. Por otro lado, está el lugar de la gestación colectiva. La vía del mito se transfiere a la de la técnica cuando se traspasa el portón del taller de Valentín Alsina (taller del veterano maquinista del Teatro Colón Miguel Biancuzzo) donde los pesos, medidas y proporciones, maquinarias y herramientas pesadas reemplazan pinceles y pinturas. Las contradicciones, marchas y contramarchas de la producción artesanal del Pulqui debe negociar cada paso entre las ideas, el cálculo material de su aplicación, el compromiso de los ejecutores y el reparto de responsabilidad entre especialistas.

Maniobra, clima, fijación obsesiva con los avatares de la obra similares a los de la gestación de un film. El documental finalmente construye su propio su sesgo reflexivo a través de las etapas de la construcción del Pulqui, - diseño, cálculos, esqueleto, piezas, montaje, del desafio de hacerlo volar, de los fracasos y recomienzos hasta llegar, "como objeto caído" a ocupar su lugar en el museo ${ }^{26}$, o ser finalmente suspendido en el espacio central del Abasto durante el $9^{\circ}$ Festival Internacional de Cine Independiente en abril pasado.

Poéticas y políticas de la forma documental, que a la vez hacen lugar a lo político con los signos de la realidad. AFM matiza el proceso (mimético) del registro con el énfasis en una figura temporal, la repetición. Cada viaje al taller es idéntico al anterior, pero en cada uno de esos sucesivos traslados la cámara, en ejercicio de su autonomía, deja ingresar un paisaje devastado - paisaje humano, de cambiantes pirámides de cartoneros desplazándose entre el tráfico de Puente Alsina sobre carros de tracción a sangre; y paisaje material, con los signos de las ruinas en aquella barriada antes industrial.

26. La exposición realizada en el Museo Provincial de Bellas Artes "Emilio Caraffa" en Octubre de 2005 se tituló "Utopia justicialista, con un objeto caido", consistió en la obra pictórica y la instalación del avión Pulqui , restaurado del aterrizaje forzoso tras su vuelo en el aeródromo de la República de los Niños, en la provincia de Buenos Aires. 


\section{Entre lo mítico y lo profano}

Estos documentales no intentan agitar ni reponer el peronismo. Sino que hacen un ejercicio indispensable de revisión y/o de interpretación histórica, sea formulando preguntas drásticas sobre las condiciones histórico políticas que pesaron para torcer las hechuras innovadoras del pasado (el relato laico de Solanas). O volviendo sobre ese pretérito con relatos de afección, con el lenguaje intemporal pero apasionado del mito (Favio, Fernández Moujan/Santoro), cuyo montaje audiovisual constituye siempre un desafio a las formas. Lenguaje que en los autores mencionados se nutrió de recursos, formatos y elementos nacidos de la significativa inspiración visual y simbólica del primer peronismo. Aunque es sabido que esa producción nunca fue honrada precisamente por el terreno del arte.

Las tres experiencias estéticas documentan zonas de ese esqueleto mítico: el movimiento nacional y popular. Juegan a la vez culturalmente, miticamente, con un tiempo "intemporal" (el que contendría el Inicio de una historia y el sentido abarcador de esa historia ahora), y un tiempo moderno profano: el presente político, inmanente, abierto. Entre esos dos horizontes estos ensayos de retroperonismo por vía del arte que citan la figura de un pájaro mecánico, de un vuelo imaginario del pasado sobre nosotros, abren interrogantes sobre el propio estadio de la relación entre estética y política en nuestra actualidad, y específicamente en la actualidad del documental. ¿De qué dan cuenta estas poéticas? ¿De una vigencia política? ¿De una memoria popular? ¿De un reencuentro con determinados significados de lo nacional que hasta hace pocos años flotaban en una bruma de la historia? ¿De una transmisión que articula un pretérito para las nuevas generaciones?

La marcada visibilidad en la escena cultural de una estética peronista filmica y mediática, emerge paradójicamente en un tiempo de crisis en los mundos simbólicos y en las identidades de la política, crisis evidente también en el peronismo. ¿Cómo interpretar en estas circunstancias el movimiento creador de volver al mito con los procedimientos estéticos del mito? De Walter Benjamin se podrían inferir dos respuestas para esta incertidumbre: el arte sería el 
mensajero moderno encargado de despedir una historia intensa, es su duelo. Pero también el lenguaje artístico muchas veces es una contestación anacrónica, crítica, que permite discernir lo que en realidad tiene lugar ahora.

Sin caer en el fácil relativismo posmoderno (mercado, consumo, espectáculos de masas, audiencias cautivas, modas retro), la pregunta lleva a pensar en la fuerza cultural del propio peronismo, que permanentemente reabre cuestiones y siempre desafia en busca de una legitimidad que la cultura y el arte oficial antes y ahora trabajosamente le conceden. Desde esta última mirada el retroperonismo - la retrospección del peronismo que realizan estos documentales - se descentra de esa dimensión de corte posmoderno, para expresar en cambio una ética posible: la de las preguntas críticas que promueve.

\section{Bibliografia}

BENJAMIN, Walter. Libro de los Pasajes, Madrid: Ed. Akal,. 2005. BUCK-MORSS, Susan. Mundo soñado y catástrofe. La desaparición de la utopia de masas en el Este y el Oeste, Madrid: La balsa de la Medusa, 2004.

DIDI-HUBERMAN, George. Ante el tiempo, Buenos Aires: Adriana Hidalgo.

GONZÁLEZ, Horacio. En Restos pampeanos, Buenos Aires: Colihue, 2000.

MARTÍNEZ ESTRADA, Ezequiel. ¿Qué es esto? Catilinarias, Buenos Aires: Ed.Colihue/Biblioteca Nacional, 2005.

NAHMÍAS, Gustavo. "Mito y dramaturgia sacramental en la interpretación histórica”, Confines No 13, diciembre de 2003.

. "Memoria y política: el caso Favio", en La memoria en el atril. Entre los mitos de archivo y el pasado de las experiencias, de Horacio González (comp), Buenos Aires: Colihue, 2005.

NICHOLS, Bill. Ideology and the Image: Social Representation in the Cinema and other Media, Bloomington: Indiana Press, 1981. 
RANCIÉRE, Jacques Le destin des images, Paris: La fabrique editions, 2003.

RENOV, Michael. "Towards a Poetics of Documentary", en Michael Renov ed., Theorizing Documentary, New York: Routledge, 1993.

SANTORO, Daniel. Mundo peronista, Buenos Aires: Ed. La Marca, Sutern, Cine Ojo, 2006. 